\title{
A Bimodal Transportation Model for Steam Coal Exportation Based on Magdalena River as Main Waterway
}

Henry Murcia ${ }^{1}$

\begin{abstract}
The aim of this work is to offer a new alternative to allow the release of the Colombian coal transportation system that nowadays is under a saturation state. For this reason it is proposed, the option of making the exportation of the surplus production granted by the thermic coal mining activity focused on the Cesar department, through a bimodal transportation system that will highlight on the Magdalena River as the most important way for the logistic development of the country. As main key and support tool, the Discrete Event Simulation (DES) methodology was used for conducting experiments based on information which has given the characterization of the proposed system. Hence, the establishment of the conceptual model that determinated and limit the system, a simulation in the software Rockwell Arena was implemented which results were tested and analyzed to study the performance of itself.
\end{abstract}

Key words: Discrete Event Simulation, thermic coal, Magdalena River, logistic development.

\section{Resumen}

Este trabajo tiene como objetivo, proponer una nueva alternativa que permita aliviar el sistema de transporte de carga colombiano de carbón que actualmente se encuentra en estado de saturación. Para esto se plantea la opción de realizar la exportación de los excedentes de producción, generados por la actividad minera de carbón térmico originaria del departamento de Cesar, a través de un sistema bimodal de transporte que hará énfasis en el Río Magdalena como arteria principal y eje potencial del desarrollo logístico del país. Como herramienta clave y de soporte, se utilizó la metodología de Simulación de Eventos Discretos (SED) con la finalidad de dirigir experimentos fundamentados en informaciones que caracterizan la propuesta presentada. Así luego de establecerse el modelo conceptual que determinó y delimitó el sistema propuesto, se implementó una simulación en el software Rockwell Arena, cuyos resultados fueron probados y analizados luego de haberse estudiado el desempeño del mismo.

Palabras claves: Simulación de Eventos Discretos, carbón térmico, Río Magdalena, desarrollo logístico.

Date Received: October $18^{\text {th }} 2014$ - Fecha de recepción: Octubre 18 de 2014

Date Accepted: December $3^{\text {rd }} 2015$ - Fecha de aceptación: Diciembre 3 de 2015

${ }^{1}$ COTECMAR - Science, Technology and Innovation Management Office. University of Săo Paulo - Department of Naval Architecture and Ocean Engineering. Email: hmurcia@cotecmar.com 


\section{Introduction}

Nowadays, the rhythm of the world's economy has experienced a high speed and accelerated growth with the industrialization for those who are known for having emerging markets. It is possible to highlight countries as China and India as the main leaders of a list twenty nations who are part of these markets.

In the same way that the economy of these emerging markets growth, the world coal demand has also been sensing a considerable increase because of the economic boom that the world is presenting since the last decades.

Instead of others energy sources as oil, gas or renewables, coal is a reliable and low price energy source that presents proven and guaranteed reserves for more than 150 years.

On the other hand, thinking about logistics approaches, coal has two important characteristics: Easy production with low technological component and a relatively cheaper transport.

Institutions as World Coal Association assert that the coal is the energy source responsible by $41 \%$ percent of the planet's electric power generation. ${ }^{1}$

According to this perspective, it is important that Colombia takes advantage of this natural resource, in function of the quality of its coal with low-ash and sulfur contents and high thermic value.

In Latin America, Colombia represents the country with highest coal reserves with $16.992 \mathrm{Mt}$, which have allocated the country since 2010 in the top ten of coal exporters as fifth in the world.

By knowing this reality, Colombia must follow the model that countries, different of named from third world, have traced for the exploitation and development of its natural resources at the same time that improves its competitive advantages with the production growth and the implementation of technology.

Source: http://www.worldcoal.org/coal-energy-access/
In fact, it establishes one of the most important recommendations that the World Bank has proposed for these countries, maintaining that a country rich in natural resources that implements efficiently the appropriate technologies must grow in a similar way as those countries that based its growth on the industrial sector.

In this way, the main motivation for the development of this work is the proposition of a system in which the natural resources of Colombia notably the coal, could be transported by an economic and sustainable alternative having the Magdalena River as the main waterway for the coal flow until the Colombia's Caribe exportation ports.

\section{Colombian Coal Market Overview}

\section{Production}

Since 1985 until 2010, Colombian coal production has experimented an exponentially growth that is attributed to the beginning of coal extraction operations in the main pits of the north zone of the country by early 1980 . See Fig. $1 .^{2}$

Fig. 1. Coal Production in Colombia. (Data in thousands of tons).

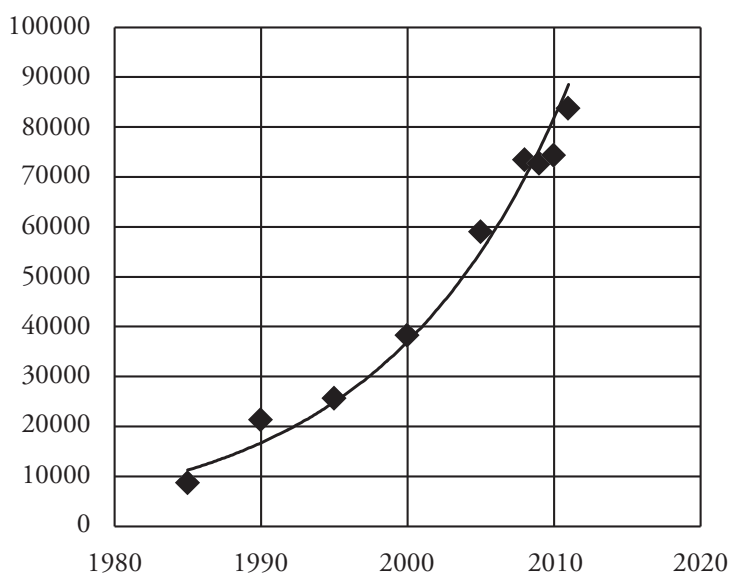

The coking coal (metallurgical coal), used on the steel and iron Industry, has not presented an important input in the total production for the

2 Figure based on data obtained from International Energy Agency "IEA STATISTICS, COAL INFORMATION 2012" 
same period (1980 and 2011 finals). Fig. $2^{3}$, shows the behavior that this kind of coal has featured over the total Colombian coal production.

Fig. 2. Coking Coal Production. (Data in thousands of tones).

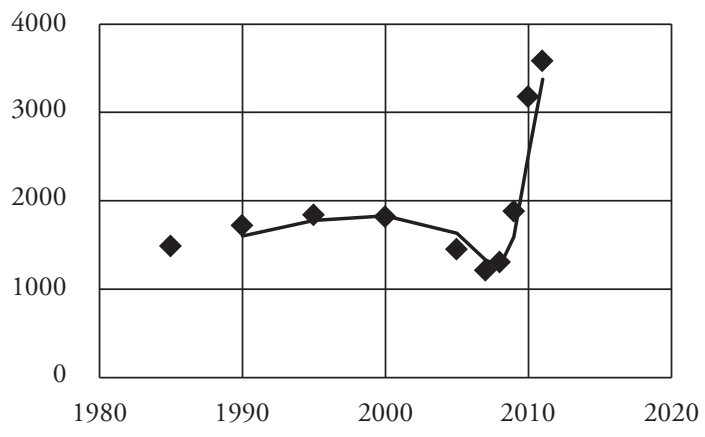

According to the Fig. 2, it is possible to observe that coking coal production presented a decrease between the years 2000 and 2008, followed by an important recovery.

Nevertheless, the steam coal production represents to the country a high participation over the total production, instead of the coking coal, as shown in the Fig. $3^{4}$.

\footnotetext{
3 Figure based on data obtained from International Energy Agency "IEA STATISTICS, COAL INFORMATION 2012"

4 Figure based on data obtained from International Energy Agency "IEA STATISTICS, COAL INFORMATION 2012"
}

Fig. 3. Steam Coal Production (Data in thousands of tones).

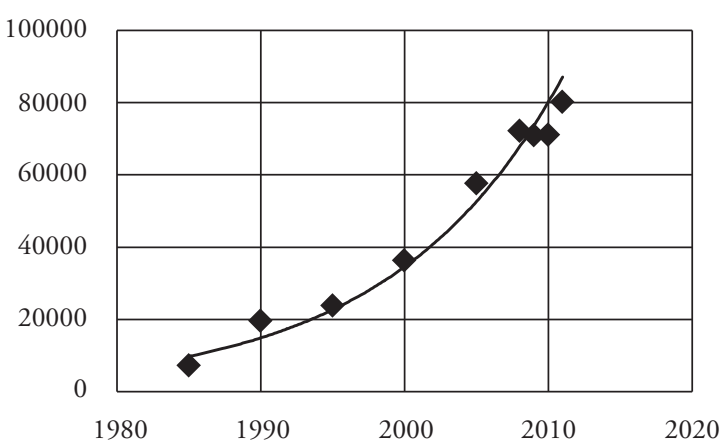

Fig. 3, shows the same period (starting in the 1980's and ending in 2011) more than $90 \%$ percent of coal production was characterized by the steam coal.

As a consequence of mineral extraction on the Colombian north zone, where are located the biggest coal reserves of the country and where important investments and development of technological level in the mining region are done.

\section{Exportation}

Founded on data from the document "Coal Information 2012" from the International Energy Agency, Fig. 4, Fig. 5 and Fig. 6 presents how have been the trends for Colombian coal exportations for the ending of 1978 until ending in 2011.

Fig. 4. Colombian Coking Coal Exportations.

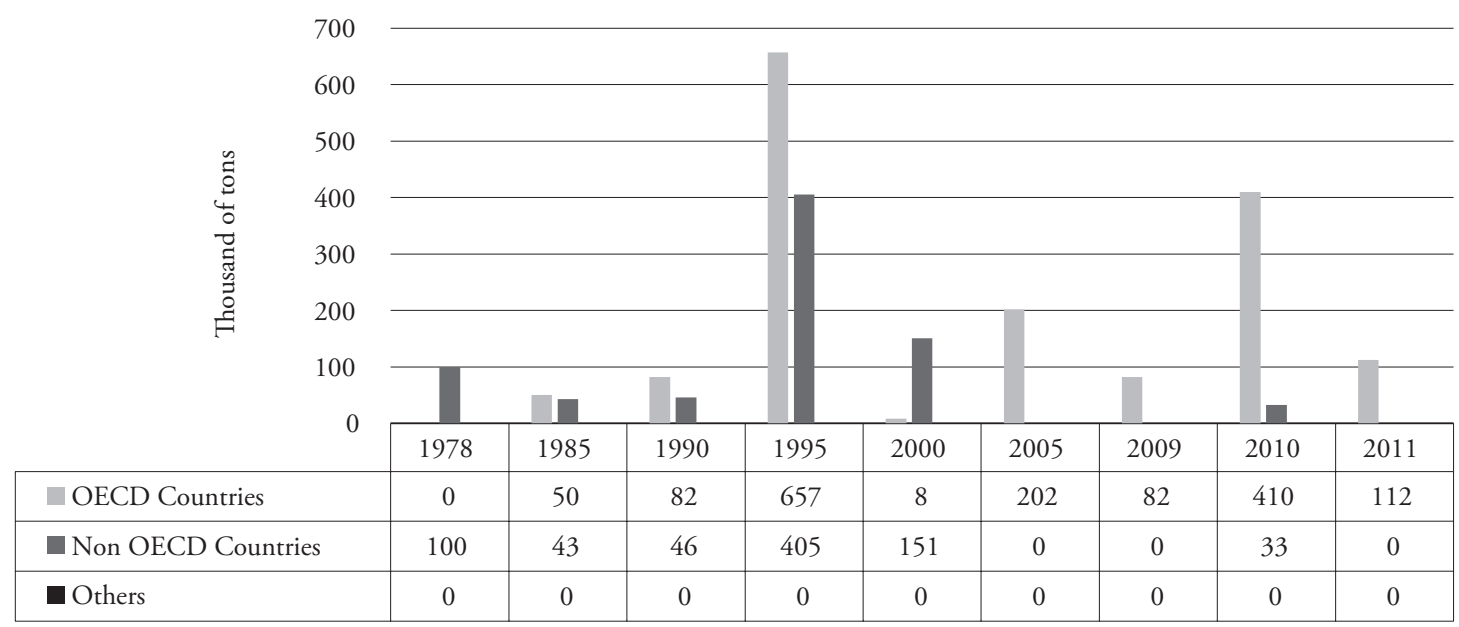


Fig. 5. Colombian Steam Coal Exportations. Data in thousands of tons.

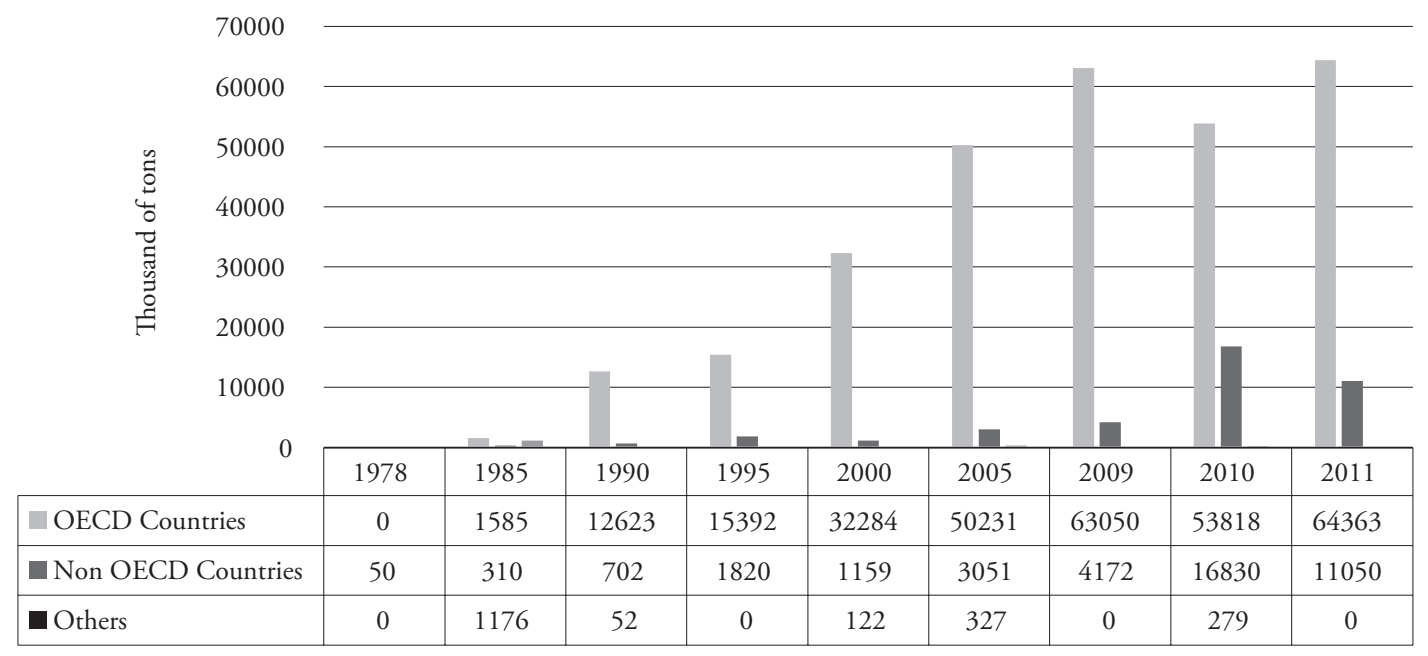

Fig. 4 shows the biggest quantity of coking coal exported in the specified period of time belongs to the coals that were assigned to the countries that are part of the Organisation For Economic Cooperation and Development (OECD). Examples of these countries are the following: Belgium, Canada, France, Japan, Portugal, Spain, Austria, Korea, Italy, Israel, etc.

Moreover, Brazil who is one the country that does not belong to OECD, Brazil, was part of the final departure destinations for Colombian coal that contributed for the total amount of the exportations.

It is possible to appreciate in the Fig. 5 the steam coal consumption for the Colombian market belongs to the OECD countries, which concentrates almost the total volume of the production made in Colombia per year.

The exportation volume of steam coal was showed in the Fig. 6, fully exceeds the level of exportation for the coking coal produced in the Colombia hinterland in more than $94 \%$ percent over the total exported in the studied period.

\section{The Cesar Department Case}

Currently, this department presents the biggest level of production for steam coal. In the year 2011, according to the Fig. 7, the Cesar Department had the biggest contribution in the national production. The 43,688 millions of tons produced in represented the $51 \%$ percent over the total production became this region as the main coal producer of Colombia.

Fig. 6. Comparison between Coking Coal Exportations and Steam Coal Exportation in Colombia. Data in thousands of tons.

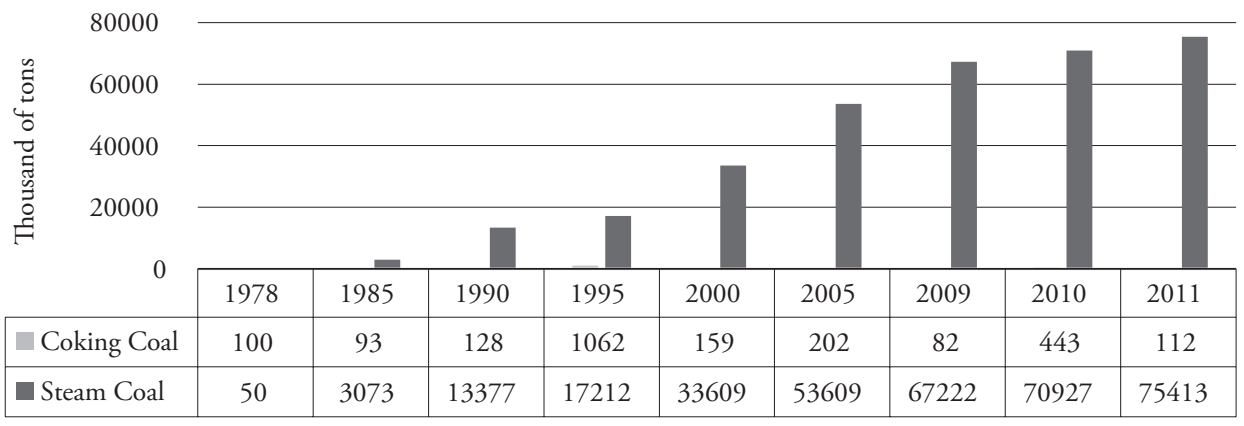


Fig. 7. Matrix of Colombian coal production by main producers centers (end of 2011).

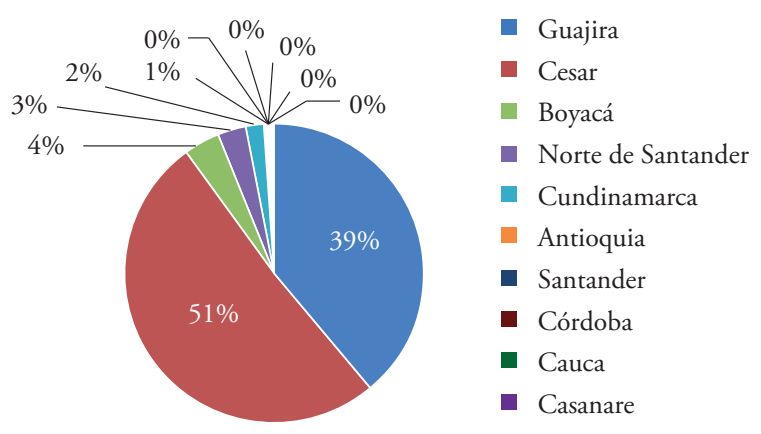

\section{Literature Review}

According to the literature, it was possible to detect that exists a conventionalism around the concepts of simulation, system and model. It is because authors have accepted definitions that authors were enriched with new pragmatics and methodological contributions without changing the original root of these concepts.

Furthermore, it was observed that does not exist a unique and fixed procedure or methodology for conducting simulation projects. Nevertheless, there are several proposals of researches as Nylor (1966), Knepell (1993), Pegden (1995), Chwif (1999), Botter (2002), Law (2007), which are the results of experience in simulation area and at the same time became tools for helping people who wants to plan or execute these kind of works.

Consequently, the methodology to the development of simulation projects is an open topic that admits new contributions every day, looking for a realistic and intuitive modeling with a structured and methodical order to apply in real life of problems.

Related to works which apply simulation methodologies as; Mendes (1999), Bugaric e Petrovic (2000), Demirci (2003), Cassettari et al (2011), Cigiloni e Rossi (2011), Kondratowicz (1990), among others, it was observed that in every case the developed models have a significant detailing level because of the need of representing real problems in a reliable way with regard to find consistent answers.
As mentioned above, it is remarkable that each one of these, were made with the purpose of serve as a decision making tool when different scenarios where tested for answering transportation and logistics problems at the level of strategic planning for companies.

Close to the affinity of researches, the work of Cabrera (1995) presents an important help for the developing of this research, because of being a specific reference related to the sizing of a multimodal transport system in Colombia by using the Magdalena River, even though the author focuses his study on container applications.

The most important conclusion taken after the reviewing of literature is that the methodology will be used by this research project is the Discrete Event Simulation, because already exist similar works where this methodology were successfully applied for solving transportation and logistics problems related to waterways terminals, multimodal systems, sizing of port facilities for bulk cargo handling.

This technique (Discrete Event Simulation DEV) at the same time showed flexibility and robustness to allow the testing of different scenarios, policies and strategies for the optimal operation of systems.

\section{Problem definition}

The main goal for conducting this work is the creation of a model that allows simulating the transportation of steam coal produced in the main pits located in the north of Colombia, especially the Cesar department, using an intermodal system and thinking about the use of Magdalena River as the main Waterway with the purpose of sizing this system.

With the processing of the model are expected as the most important results the configuration of the fluvial fleet and the bimodal terminal, focused on the sizing of berths and coal storage required for attending the coal transport demand in twenty year planning horizon for a set of origins, departures and pre-defined transport modals. 
The facilities for trucks coal loading in the producers centers will be not object of sizing and neither the road fleet required for transferring the coal to the intermodal terminal. It will be assumed that the road fleet will be contracted in a spot market and also that trucks are always available for operating in the system.

The model will be used by tracking the level of service, in such way that the system resources will have its capacities fixed for allowing to attend the exportation of coal demand per year during the defined period of time.

In that order of ideas, the main procedure for solving this sizing problem will concentrate efforts for identifying the minimum capacity and quantity of resources per year with the aim of guarantee the Colombian steam coal exportations.

\section{System Characterization}

The proposed system will have the following structure, see Fig. 8.

Fig. 8. System structure.

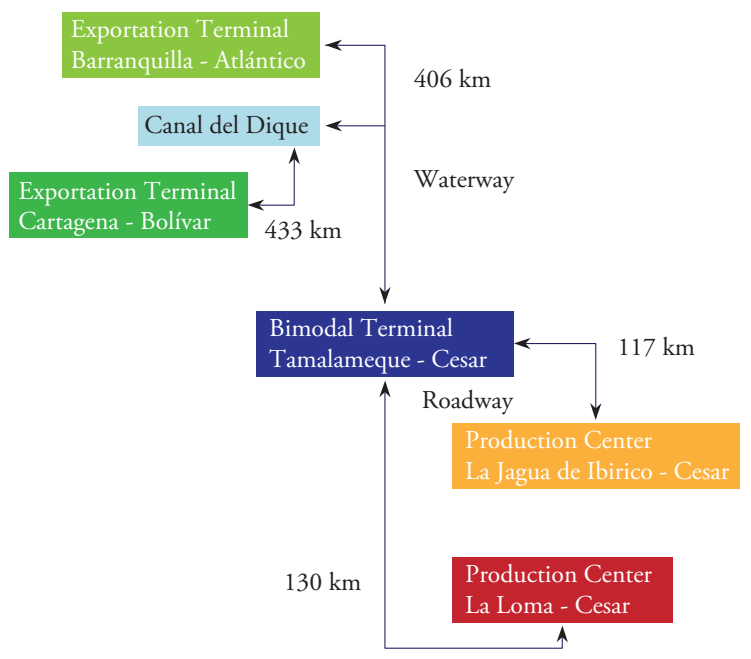

As shown in the figure 8 , the proposed system will be composed by these elements:

- 2 Steam coal main producers centers

- 1 Intermodal terminal

- 2 Exportation terminals
For this system is desired to transport the surplus production of steam coal which has as main origins the municipalities of La Jagua de Ibirico and El Paso by mean of roadway until the municipality of Tamalameque. All these interest points are sited on Cesar department. According to the Fig. 9.

Fig. 9.

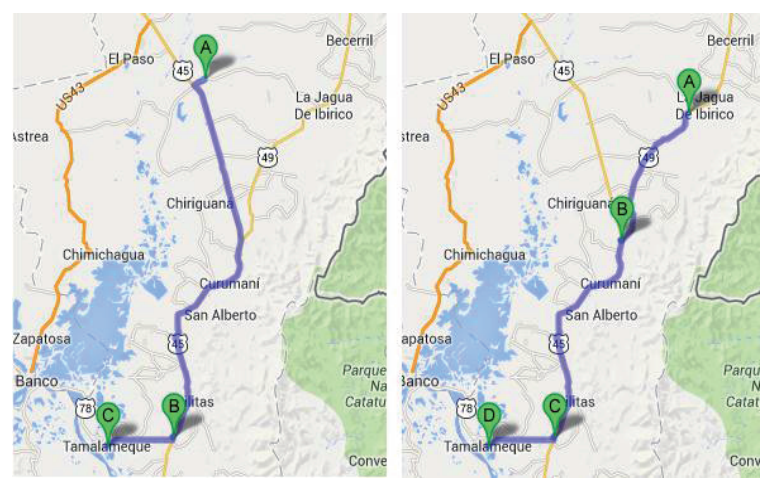

In the municipality of Tamalameque, the actual inland port will be used for the implantation of an intermodal (bimodal) terminal (interconnection between roadway and waterway).

The steam coal cargo will arrive to the mentioned terminal and there will be stored in a patio for being transferred to the river fleet that will be departure to the maritime ports of Cartagena and Barranquilla. see Fig. 10.

Fig. 10.

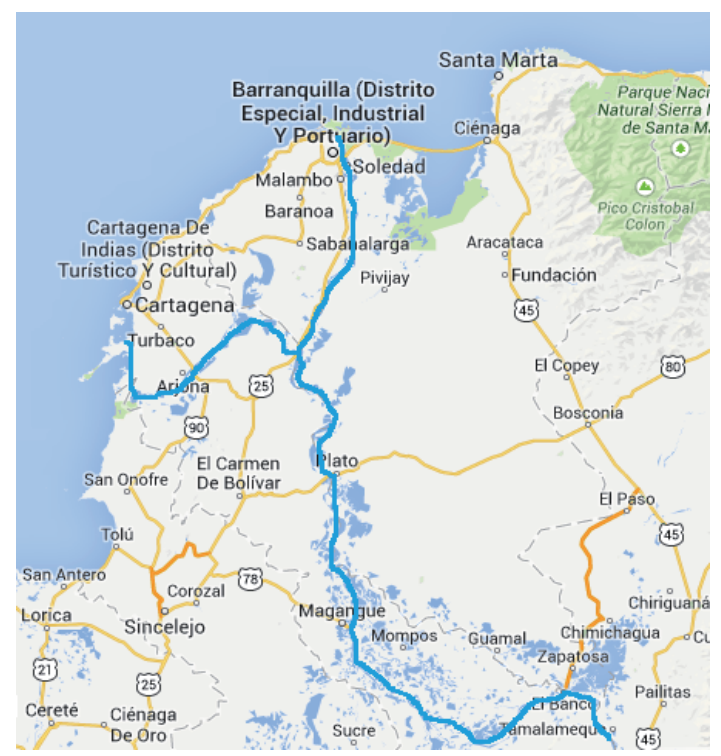


Considering the description above, the system can be characterized by the following subsystems:

\section{a. Production Subsystem}

The steam coal production will be focused on Cesar department. Here the main producers municipalities will be La Jagua de Ibirico and El Paso.

\section{b. Roadway transport subsystem}

This subsystem will be compound by the road element of the entire system, which is the only way for transferring the thermal coal produced until the bimodal terminal of Tamalameque, where the mineral will be stored.

\section{c. Transhipment terminal subsystem}

Here will be modeled the inland Tamalameque terminal, that will be the interface between the road modal and the waterway.

\section{d. Waterway transport subsystem}

The maritime ports of the north of Colombia (Cartagena and Barranquilla) will be linked with the intermodal terminal of Tamalameque by using this subsystem.

\section{e. Exportation subsystem}

The operations of exportations ports characterize the final subsystem of the proposed model.

\section{Simulation Model and Results}

By knowing the main problem and characterizing the system, a simulation model made in Arena 14, was developed for conducting experiments in order to size the proposed system.

It was necessary to define the main patron scenario. This scenario is:

"Transport of surplus production from thermal coal produced in the south region of Cesar department - Colombia, based on the expected demand forecast for a planning horizon of twenty years (2015 until 2035), through an intermodal system type: road, since the producers centers of La Loma (CES) and La Jagua de Ibirico (CES) until an intermodal terminal in Tamalameque (CES); waterway, since the intermodal terminal of Tamalameque, sailing the lower and middle zones of Magdalena River and the Canal del Dique with destination to exportations ports of Cartagena (BOL) and Barranquilla (ATL).

Using the main scenario as described above, a set of variables were determinated within its range of values with the purpose of testing the combinations of these looking for the best configuration that will size the proposed system.

These variables were:

- Coal loading positions in production center 1.

- Coal loading positions in production center 2.

- Coal unloading positions in the intermodal center.

- Coal barge loading positions for the intermodal center.

- Stock capacity for storing coal in the intermodal terminal.

The following assumptions were also considered:

- The five main points of the system have patios for storing the coal and works $24 \mathrm{~h}$ per day.

- The convoys are composed by one Tugboat and a set of six barges using the configuration $2 \times 3(\mathrm{R}-2 \mathrm{~B}-2 \mathrm{~B}-2 \mathrm{~B})$

- There is not a flow of imported coal.

- There is not operations of barge fragmentations

- The river draught through the year has variability on its value between $6 \mathrm{ft}$ and $8 \mathrm{ft}$.

- The system must allow the exportation of 400.000 tons at the end of the first year and must be capable of exporting 8 million tons by the end of the planning horizon.

With all these definitions were conducted the simulations ${ }^{5}$ of the system for a time period of 20 years and 7 replications.

The obtained results were studied using a $t$ distribution for a 5\% level of significance in its confidence intervals.

Finally, after conducted 21 scenarios simulations were found the best configuration for the proposed

5 All simulation parameters and values will be showed in the annexes. 
system by determining the best values for sizing the intermodal terminal with:

- A total number of 19 river convoys at the end of the 20 years.

- 12 coal unloading positions for trucks.

- 2 coal loading positions for barges.

- 10.000ton storage capacity for stocking coal.

All these results were validated to use performance measures ${ }^{6}$ for attending a level of service in order to avoid the presence of queues on every point in the system. Even more, these sizing results were evaluated by a sensibility analysis where was studied the performance of the system to study the effect of operations with barge fragmentations, the presence of a fixe draught and variation in coal demand.

\section{Conclusions}

This research focused on the proposition of a new alternative system for exporting the surplus production of thermal coal produced in the main pits of La Jagua de Ibirico and La Loma, both located on Cesar department of Colombia, with the aim to satisfy a 20 year forecast demand of the mineral for using a bimodal transportation option where the middle and low part of Magdalena river is showed to promote the development of the waterway thinking in the capabilities that the river can offer for exporting goods.

Based on the main geographic and interest points, it was used a discrete event simulation methodology for conducting experiments where was possible to find the best configuration for sizing the intermodal terminal that will link the road modal and the waterway required to export the thermal coal to the ports located in Cartagena and Barranquilla.

According to IEA statistics for the coal demand forecast, it was used a compound annual growth rate of $0,9 \%$ percent for attending the coal demand for the next 20 year. This rate represented approximately the exportation of coal with an

\footnotetext{
6 These measures will be presented in the annexes.
}

annual growth of 400.000 tons, which required an optimal quantity or resources in the system to avoid congestion in order to attend a level of service for satisfying the expected amount of the mineral.

\section{Bibliography}

1. BOTTER, R. (2002). "Tratamento de Dados em Modelos de Simulação Discreta". Tese de Livre Docência - EPUSP (Escola Politécnica da Universidade de São Paulo). São Paulo.

2. BUGARIC, U., \& PETROVIC, D. (2000). "Modelling and Simulation of Specialized River Terminals for Bulk Cargo Unloading".

3. CABRERA, J. (1995). "Transporte Intermodal en el Corredor Central de Colombia". PNV USP (Departamento de Engenharia Naval e Oceânica Escola Politécnica da Universidade de São Paulo). São Paulo.

4. CASSETTARI, L., MOSCA, R., REVETRIA, R., \& ROLANDO, F. (2011). Sizing of a 3,000,000t Bulk Cargo Port Through Discrete And Stochastic Simulation Integrated With Response Surface Methodology Techniques. Proceedings of the 11th WSEAS international conference on Signal processing, computational geometry and artificial vision, and Proceedings of the 11th WSEAS international conference on Systems theory and scientific computation, 211216.

5. CHWIF, L. (1999). "Redução de Modelos de Simulação de Eventos Discretos na Sua Concepção: Uma Abordagem Causal". Tese de Doutorado - EPUSP (Escola Politécnica da Universidade de São Paulo). São Paulo.

6. CIGOLINI, R., \& ROSSI, T. (2010). Sizing Off-Shore Transhipment System in Dry-Bulk Transportation. Production, Planning and Control, 508-522.

7. DEMIRCI, E. (2003). Simulation Modelling and Analysis of Port Investment. Simulation, 94-105. 
8. INTERNACIONAL ENERGY AGENCY. (2012). "IEA Statistics, Coal Information". Paris.

9. KONDRATOWICZ, L. (1990). Simulation Methodology for Intermodal Freigh Transportation Terminals. Simulation, 49-58.

10. LAW, A. (2007). Simulation Modeling and Analysis. McGraw-Hill.

11. MENDES, A. (1999). "Modelo Econômico - Operacional para o Dimensionamento do Transporte Intermodal de Cargas pela Hidrovia Tietê - Paraná". Dissertação de Mestrado EPUSP (Escola Politécnica da Universidade de São Paulo). São Paulo.
12. NAYLOR, T., BALINTFY, J., BURDICK, D., \& CHU, K. (1971). "Téenicas de Simulação em Computadoras". São Paulo: Editora da Universidade de São Paulo.

13. PEGDEN, D., SHANNON, R., \& SADOWSKI, R. (1995). "Introduction to Simulation Using Siman". Blaklick: McGrawHill.

14. PETER, K., \& ARANGNO, D. (1993). "Simulation Validation: A Confidence Assessment Methodology". IEEE.

15. WCA. (2013). World Coal Association. Acesso em 28 de Janeiro de 2013, disponível em http://www.worldcoal.org/coal/market-amptransportation/ 